\title{
The Morpho-Semantic Aspects of the Derived Triliteral Verbs of the Qur'ân
}

Iman Ahmad Ibrahim

\section{Abstract}

According to Arabic morphologists, there are about fifteen verb forms in Classical Arabic, i.e. the variety of Arabic mostly used in the Glorious Qur'ân. Five of the fifteen forms are rare. The other ten have one basic form, i.e. [façala]. There are nine derived forms. Therefore, this paper begins with Form II. The paper is concerned with the semantic functions as well as the semantic fields of each one of the forms. Another concern of the paper is the comparisons between the semantic indications of each one of verb forms pairs such as the pair of /nazzala \& Panzala/ as they are used in the Holy Qur'ân. The comparisons are based on the books of Morphology as well as the exegeses of the Qur'ân.

The researcher discovers that the verb forms are used in the Holy Qur'ân to express certain meanings that are different to some extent than those expressed by the same forms in Modern Standard Arabic.

The nine forms are mentioned in details as follows:

Form II: [faççala] فَعَّلَ

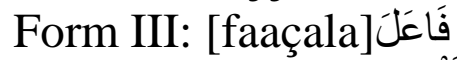

Form IV: [ح

Form V: [tafaççala] تَفََّلَ

Form VI: [tafaaçala] تَفَاعَل

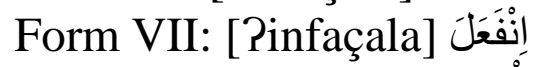

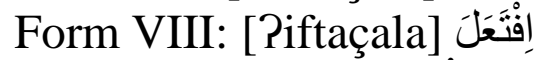

Form IX: [?

${ }^{(*)}$ This paper is a part of $\mathrm{PhD}$. thesis entitled: " Morpho-semantic Aspects of the Translation of Trilateral Verb Forms in the Holy Qur'an into English ". Supervised by Prof.Bahaa-eddin M.Mazid- Faculty of Languages - Sohag University \& . Dr.Hanan Abu-Altaher Ebeid Faculty of Arts - Sohag University. 
Form X: [Pistafçala]

\section{Key Words:}

Morphology, Semantics, Derived Triliteral Verb Forms, Trilateral Verb Translation, and Glorious Qur'ân.

\section{Introduction}

The researcher presents the derived forms in a certain sequence. First, the number of the verbs comes in the mentioned form within the Glorious Qur'ân. Second, the percentage of this number of the whole verb forms used in the Qur'ân. Third, the list of verbs used in this form. Fourth, the semantic functions of each form and some examples of this form and/or the verbs that are used to achieve these semantic functions. Fifth, the semantic fields that the verbs of each form are used for, Finally, there are some comparisons including the semantic indications of certain groups of couple verb forms which have similar structure but differ in some semantic aspects.

The study uses the translation of Mohammad Mahmoud Ghali for the verses in which the examples of verb forms are used since, according to Enani, Ghali is the only translator who made a specific translation for each one of the verbs /yax̌saal, lyaxaafl and /yattaqi/ 'fear' in spite of their very close meanings. Ghali is the only translator who could, by the use of his intention or scientific approach or both of them; achieve the aim of Nida through the analysis of the elements of meaning for the above-mentioned three verbs.

\section{Questions of the Study}

The paper tries to answer the following questions:

1. What are the semantic indications of the derived triliteral verb forms in the Holy Qur'ân?

2. What are the specific indications of each verb form in the Holy Qur'ân that differ from those ones expressed by the same forms in Modern Standard Arabic?

\section{6}




\section{Method of the Study}

To answer the previous questions, the researcher studies all the semantic indications and semantic fields of each triliteral verb form according to the books of Morphology and the exegeses. The second stage is the comparisons the researcher makes between pairs of verb forms that are used reciprocally to express similar meanings in the Holy Qur'ân and stating the specific semantic indications of each form.

\section{Semantic Analysis \\ Form II [faççala]}

This verb is formed by doubling the middle radical of the verb. In order to make it easy for writing, a diacritic called /šaddah/ is put in the Arabic script over the middle letter instead of writing it twice. According to Al-Kufi (1989: 25), there are about one hundred seventy verbs of the form [faççala] in the whole Qur'ân. The number is mentioned neatly in AlSwalaqah's (2008: 2) chart as she said that the verbs are 168 ones with a percentage of $21.5 \%$ of the whole verb forms in Qur'ân and it comes at the second rate of verb forms of Qur'ân.

\section{Semantic Functions of [faççala]}

In this paper, the researcher mentions the meanings expressed by this form in the Glorious Qur'ân. Al-Saçdy (2011: 3-9), AlSayed (2004: I/62) and Idris (1989: II/593) agree in listing the following semantic functions:

\subsubsection{The meaning of intensity}

As this form is usually used to give the meaning of intensity, some of the Arabic language scholars may think that this is the only form to express intensity. Some examples of this meaning are:

a. Igallaqat/ in Surat Yusuf, verse no. 23 : "and bolted the doors (on them)" 
b. Ifala-yubattikunnal in Surat An-Nisaa', verse no. 119 : “and indeed I will definitely command them (and) so indeed they will definitely cut off the cattle's ears."

Note that not only the transitive verbs assign the meaning of intensity to the form [faççala] but also the intransitive ones, as Idris notes for an example of the verb /yuçaqqib/ of Surat AnNaml,verse no. 10 :

"he turned away withdrawing and did not retrace his steps." Az-Zmakhashari explains that the meaning of the verb /çaqqaba/ 'retrace' indicates the repetition as it means turning around after fleeing.

Idris (1989:II/587-8) adds to the first meaning of the verb [faççala], i.e. intensity, that there are three levels of intensity as follows:

a. Intensity of verb, e.g.1 /qaTTaça $\mathrm{Pa} \underline{\theta-\theta w a b /}$ 'cut off the dress', e.g. 2 /fajjara Pan-nahr/ 'burst the river'.

b. Intensity of subject, e.g. /barrakat Pil-Pibl/ as the verb of kneeling down increased among the camels.

c. Intensity of object, e.g. Igallaqat Pil-Pabwaab/ 'bolt the doors'.

\subsubsection{To give the meaning of the form [tafaççala]}

As the verb /yumassikuunal in Surat Al-'Açrâf, verse no. 170:

"And the ones who hold fast to the Book and keep up the prayer; surely We do not waste the reward of the righteous doer."

\subsubsection{To derive a verb from a certain noun}

As the verb /çabbad-tal (the verb is assimilated into çabbat-ta) in Surat Ash-Shuçaraa', verse no. 22:

"And is that a favor you oblige me with, that you have taken the Seeds (Or: sons) of Israel), as slaves."

\subsubsection{To do something in the time that the verb is derived from}

As the verb /Sabbahal in Surat Al-Qamar, verse no. 38: 
"And indeed there already came upon them before sunrise a settled torment."

The verb means that the torture came at dawn so that they all died.

\subsubsection{To determine a certain time for doing something as in Surat Al-'Ançam, verse no. 128:}

"And their patrons among humankind will say, Our Lord; we have enjoyed (privileges) with one another, (Literally: some of them with some others) and we have reached the term You have appointed for us."

Al-Sayed (2004: I/63) adds the verb /Sabbaha/ to the previous verb /Pajjala/ to express this meaning.

The following meanings are mentioned by both of Al-Sayed and Idris.

\subsubsection{To express the transitive mood.}

Idris divides these verbs into two groups:

a. to change the intransitive verbs to transitive ones as the verb /Oabbatal in Surat Al-Isrâ', verse no. 74:

"And if we had not made you stand firm, indeed you were already almost about to (seek) support from them a (very) little."

Note that changing the intransitive verbs into transitive ones can be used through the form [?afçala] or[faççala].

Alkufi (1989: 49) adds other examples to this group as the verb Inaççamal

'To make live in luxury' in Surat Al-Fajr, verse no. 15:

"Then, as for man, just when his Lord tries him, so He honors him, and showers His favors on him, then he says, My Lord has honored me."

b. To change the transitive verbs of one object to transitive ones of two objects as the verb /nabbi?/ in Surat Al-Hijr, verse no. 49: 
"Fully inform My bondmen that I, Ever I, am The EverForgiving, The Ever-Merciful."

Al-Sayed (2004: I/63) also gives a list of the verbs in the glorious Qur'ân that were used to change the transitive verbs of one object to transitive verbs of two objects as shown in appendix 2 .

\subsubsection{To give the meaning of dispossessing}

As the verb /kaffaral in Surat Al-Çimrân, verse no. 193:

"so forgive us our guilty (deeds)."

Idris (1989: II/601) quotes from Abu-Hayan that the verb lyukkafir/ means to remove the deserved punishments of the bad deeds so that they appear as if they were not done.

Al-Sayed (2004: I/63) gives a list of the verbs in the glorious Qur'ân that are used to express this meaning as follows:

/harraDal, 'provoke' /Sallaal 'pray', /çaððabal 'torture', /fazzaçal ' arouse horror in', /kaffaral 'charge with infidelity'.

\subsubsection{To express the meaning of the form [façala]}

As the verb /suççirat/ 'is blazed' in Surat At-Takwîr, verse no. 12:

"And when the Hell-Fire will be set blazing,"

Note that Al-Sayed (2004: I/63) added other verbs that express the form [façala] in the glorious Qur'ân as shown in Appendix 3.

\subsubsection{To express the meaning of the verb [?afçala]}

As the verb /yunjikum/ 'deliver you' in Surat Al-'Ançam, verse no. 64:

"Say, Allah safely delivers you from them and from every agony; thereafter you associate (others) with Him."

Al-Sayed (2004: I/ 62, 63) makes a list of seven meanings that are expressed through the use of this form in the glorious Qur'ân. 
3.1.10. The form is used to express the intransitive mood

As the coming verbs: /Paððana/ 'call out', /Pallafa/ 'put affection', /çaqqaba/ 'retrace', /qaddasa/ 'glorify'.

,e.g. /Paððana/ Surat Yûsuf, verse no. 70:

"Thereafter a crier announced, (Literally: an announcer announced), $O$ you (of) the caravan, surely you are indeed thieves!"

\subsubsection{To express the meaning of [tafaççala]}

As follows: /fakkara/ 'think', /massaka/ 'make hold', /wallaa/ 'turn back'.

, e.g. the verb /massaka/in Surat Al-'Açrâf, verse no. 170:

"And the ones who hold fast to the Book and keep up the prayer, surely We do not waste the reward of the righteous doer."

Note that As-Saçdy only mentions the following meanings of this form

\subsubsection{To make someone able to do something}

As the verb /kaffalal 'sponsor' in Surat Al-Çimrân, verse no. 37:

"and He made Zakariyya (Zechariah) her sponsor."

3.1.13. To give a new meaning that differs from that meaning of Form I of the same root

As the verb /kallama/ 'to speak with someone' in Surat AnNisaa', verse no. 164 that differs from the verb /kalama/ which means 'to hurt someone'.

"and to Mûsa (Moses) Allah spoke long, (eloquent) speech."

\subsubsection{To direct towards the place where the verb is derived from}

As what has happened to Pharaoh in Surat Yunus, verse no. 92:

"So today We will (safely) deliver you with your body that you may be a sign to the ones succeeding you;" 
Al-Saçdy quotes from Al-Tabary that the verb /nunajjiik/ means to leave the body of Pharaoh in a certain high place over the surface of the sea so that his dead body can easily be seen by the sons of Israel and the people succeeding to Pharaoh. The researcher thinks that /?an-najaah/ 'saving' here does not mean that Pharaoh will be alive but that his body will be saved so that it helps the people who succeed him know the result of disobeying and contradicting Allah's decrees.

\section{1.15. To attribute something, i.e. the origin of the verb to the object of the verb}

As in Surat Al-Ançam, verse no. 33:

"Yet surely they do not cry lies to you, but the unjust (people) repudiate the signs of Allah."

In this verse, the disbelievers attribute lying to the prophet (PBUH). Al-Sayed (2004: I/ 63) also adds the verb /zakkaa/ to the previous verb /kaððaba/ to express this meaning.

\subsubsection{To show something}

As the verb /ballaga/ in Surat Al-Maidah, verse no. 67:

"O you Messenger, proclaim whatever has been sent down to you from your Lord; and in case you do not perform (that), then in no way have you proclaimed His Message; and Allah safeguards you from mankind. Surely Allah does not guide the disbelieving people."

Al-Saçdy (2011-8) quotes from An-Nahas in his book Maçany Al-Qurân_that the verb in this verb has one of two meanings: the first one is to proclaim all that has been sent down to the messenger of Allah and the second meaning which is accepted by most of the scholars is to show what has been sent down to you, i.e. the messenger and this meaning is proved by the last part of the verb: "and Allah safeguards you from mankind." 


\subsubsection{The opposite of the verb [?afçal]}

An example of a verb in this meaning is in Surat Al-'Ançam, verse no. 31:

"The ones who have cried lies to the meeting with Allah have already lost until, when the Hour comes to them suddenly, they will say, "Oh, alas for us, for whatever we neglected in it." And they will be carrying their encumbrances (Literally: whatever "they are encumbered with") on their backs. Verily odious are the encumbrances they bear!"

In this verse the verb /farraTTnal means that they have a shortage in their life and this is the opposite of the verb /?afraT/ which means to exceed the normal limit of doing something.

\section{Form III [faaçala]}

This form is composed by the addition of the letter/?alif/ after the first letter of the verb, i.e. the /faa?/.

\section{Semantic Functions of [faaçala]}

Idris (1989: II/ 666) gives this form four main usages as follows:

\subsubsection{Indicating the participation}

Idris mentions all the verbs that come in the glorious Qur'ân of this form and indicate this meaning:

-/saabaqal 'compete', verse no. 21 of Surat Al-Ĥadîd -/kaatabal 'correspond', verse no. 33 of Surat An-Nûr

-/jaadalal 'dispute', verse no. 68 of Surat Al-Ĥaj

-/haadadal 'turn aside from', verse no. 63 of Surat At-Tawbah -IxaalaTal 'be in contact with', verse no. 220 of Surat AlBaqarah

-/maaraal 'argue with', verse no. 22 of Surat Al-Kahf

-Inaajaal 'confide a secret to', verse no. 12 of Surat AlMujaadalah

-/šaaqqal 'fill with interest', verse no. 13 of Surat Al-Anfaala 


\subsubsection{Indicating the meaning of the form [façala] to express} the meaning of exaggeration and not the meaning of participation such as the following frequent reading:

- Verse no. 16 of Surat Al-I'srâ', the verb /Paamara/ that means to increase the number of luxurious people according to Idris. "And when We will to cause a town to perish, We command its (people) luxurious (life), then they committed immorality therein; so the Word came true against it, (and) then We destroyed it an utter destruction."

- Verse no. 43 of Surat An-Nisaa', the verb /laamasa/'to touch or be in touch'.

- Verse no. 62 of Surat Al-Kahf, the verb/jaawaza/'exceed the proper bounds'.

- Verse no. 38\&40 of Surat Al-Hajj, the verb /daafaçal 'support'.

- Verse no. 9 of Surat Al-Baqarah, the verb /xaadaçal 'deceive'.

- Verse no. 85 of Surat Al-Baqarah, the verb /faadaa/ 'redeem', note that the verb is used, according to Idris, to express two meanings, i.e. the participation and to express the meaning of the form [façala].

- Verse no. 51 of Surat Al-Baqarah, the verb /waaçada/" make an appointment with', this verb also according to Idris, has two meanings, i.e. to express the participation and the meaning of the verb [façala].

- Verse no. 286 of Surat Al-Baqarah, the verb /Paaxaða/ 'has grasp'.

\subsubsection{Managing without [façala]}

This means that this form [faaçala] can be used to express a meaning that cannot be expressed by the form [façala] such as the following verbs:

a- The verb /raawada/ 'tempt' of Surat Yusuf, verse no. 26 and 30 . 
b- The verb /gaadaral 'depart' of Surat Al-Kahf, verse no. 47.

c- The verb /baaraka/ 'bless' of Surat Al-Anbiyaa', verse no. 71 .

d- The verb /waara/ 'hide' of Surat Al-Maidah,verse no. 31.

\subsubsection{Indicating the meaning of [Pafçala]}

Idris lists certain frequent readings of verbs that come in the form of [faaçala] to express the meanings of [?afçala] such as the verb /saaraça/ in Surat Al-Mu'minun, verse no. 61 which means both the meaning of participation and the meaning of the form [?afçala].

\section{Form IV [?afçala]}

This form is composed by the addition of / Palhamzah/ before the first letter /faa?/.

\section{Semantic Functions of [?afçala]}

According to Al-Kufi (1989: 25) there are 243 verbs in the glorious Qur'ân of this form. But Al-Sawalqah (2008: 2) asserted in her prescriptive statistical study that they are 241 with a percentage of 30.8 of the whole glorious Qurân. AlSawalqah quoted from Sibawayh certain meanings are expressed by the form [?afçal] as follows:

Making, attacking, negating the distinctive actions, supplicating, exposing, becoming, existing, the meaning of the verb [façala] and the meaning of the verb [faççala]. She added that Ibn Yaçîsh said that this form is used to express the meanings of dispossessing, supplicating, becoming and changing the intransitive verbs into transitive ones and she mentioned that he added in his book Sharh Al-Mufaŝl other three meanings, i.e. exposing, making and existing.

Al-Sawalqah quotes from Ibn Çaŝfûr that there are about eleven meanings are expressed by this form as follows: 
Making, attacking, lightening, negating the distinctive actions, calling, supplicating, exposing, becoming, deserving and existing.

In addition, Al-Kufi (1989: 25) quotes from Ibn-Hayan that they are more than twenty verb meanings. Most popular of them are changing the intransitive into transitive, becoming, disposing, making something strong, exposing, entering into something as a time, place or judgment, coinciding, deserving and supplicating.

\section{Form V [tafaççala]}

This form is composed by adding the $/ \mathrm{t} /$ at the beginning of the verb and the doubling of the /f/, i.e. the middle letter of the verb such as the verb /tabawwa?a/ 'to be laden'.

\section{Semantic Function of [tafaççala]}

According to Al-Kufi (1989: 29) there are eighty-six verbs of this form in the noble Qur'ân. Al-Kufi adds that some of those verbs are valid for the form [faççala] and the form [faaçala]. Concerning the meanings of the form [tafaççala], Al-Swalqah (2008: 70) quoted from Sibawayh the meanings as follows: Affectation, the meaning of the form [façala], taking from something step by step, deceitfulness and snatching. She also quoted from Ibn Yaçish other meanings such as the valence of the form [faççala], the meaning of the form [?istafaçala], the adoption of something, the work within a period of time and the avoidance of something.

\section{Form VI [tafaaçala]}

This form is composed by the addition of the letter/taa?/ before the first letter /faa?/ and the letter / Palif/ after the second letter /çain/.

\section{Semantic Functions of [tafaaçala]}

Al-Swalqah (2008: 82) quotes from Ibn-Yaçish certain meanings of this form as follows: Giving the impression of 
something, the meaning of the form [façala], participation of two persons or more $\&$ the valence of verbs of the form [faaçala].

\section{Form VII [?infaçala]}

This form is composed by adding the prefix/in/ to the origin form [façala].

\section{Semantic Functions of the form [?infaçala]}

According to Al-Kufi (1989: 27) there are fifteen verbs of this form in the noble Qur'ân as shown in Appendix 4.

Al-Kufi states (1989: 60) that this form is used for the reflexive meaning and it indicates that the object of the verb is easily affected by the action done by the subject such as the example /fatahtuhu fanfataĥ/ 'I opened it and it was opened' as a contrast to the reflexive mood of the form [?iftaçala] that indicates the repetition of the action done by the subject such as the example /naŝahtuhu fantaŝaha/ 'I advised it and he was advised'.

\section{Form VIII [?iftaçala]}

This form is composed by the addition of /hamzat PalwaSl/ before the first letter /faa?/ and the letter /taa?/ after the first letter /faa?/.

\section{Semantic Functions of the Form [?iftaçala]}

Al-Sawalqah (2008: 90) lists some meanings that are expressed by this form in the noble Qur'ân as follows:

1- The meaning of the form [façala]

2- The meaning of reflexivity

3- The meaning of participation

4- The meaning of adoption

5- The meaning of affectation

6- The meaning of [?istafçala] 


\subsubsection{The meaning of the form [façala]}

Al-Sawalqah (2008: 91-92) says that most of the meanings expressed by this form are the meanings of the form [façala], She adds that the verb /Pitaka?a/ 'recline' is used with the meaning of doing without [façala] as the form [façala] of this verb has no meaning. In addition, she quoted from Sibawayh the meaning of kidnapping and quoted from Al-Sayed that the verb / Pistaraqa/ has been used for this meaning, i.e. kidnapping but Ibn Manthur has considered the verb /Pistaraqa/ 'peek' to give the same meaning of the form [façala] the same as /saraqal 'steal'.

\subsubsection{The meaning of reflexivity}

Al-Sawalqah (2008:9) lists the verbs of this meaning as shown Appendix 5.

\subsubsection{The meaning of participation}

Al-Swalqah adds a list of the verbs that give the meaning of participation as shown in Appendix 6.

\subsubsection{The meaning of adoption}

Al-Sawalqah gives this form a list of the following verbs:

/PiSTafa/ 'has chosen', /PiSTanaçal 'has caused something to exist', /Piçtaðaral 'has made an apology', /Piqtadal 'has followed' \& /Pittaqa/ 'has stayed clear of'.

\subsubsection{The meaning of affectation}

This meaning indicates that the doer of the verb behaves in an exaggerating manner.

Al-Sawalqah (2008: 96) lists all the verbs of the Qur'ân that express this meaning as follows:

/Pijtanaba/'avoid',/Pihtamala/'bear',/Pirtadda/'retract',/Pistama ça/'listen', /PiSTabara/ 'be patient'/, /Piçtabara/ 'estimate the worth' \& /Piktasabal 'acquire'. 
Al-Sawalqah comments on the verbs /Piktasaba/ \& /Pihtamalal that some scholars consider them have the same meanings of the form [façala] but Al-Qurtuby and Al-Samin Al-Halaby see that the verb /Piktasabal differs from /kasabal and the verb /Pihtamala/ is seen by Ibn-Manthur to be different from the verb /hamala/ 'bear'\% Furthermore, the verb /Pirtadda/ is seen by Al-Sayed to be different from the verb /radda/ 'respond'.

\subsubsection{The meaning of [Pistafçala]}

Two verbs are said to express this meaning in the noble Qur'ân: /PiçtaSamal 'refuge', /Piktatabal 'subscribe'.

Al-Sawalqah adds that the verb /Piktataba/ is seen by-onlyAbu-Ĥayaan to express the meaning of affectation.

\section{Form IX [?ifçalla]}

This form is composed by the addition of /hamzat PalwaSl/ before the first letter of the verb /faa?/ and the doubling of the third letter /laam/.

\section{Semantic Function of the Form [?ifçalla]}

Al-Kufi (1989: 28) says that this form is formed by the addition of the /hamzah/ and the doubling of the /lam/ of the verb. She added that this form is used in describing the increase of a certain colour such as the verb /PibyaDDal 'turn white'. Furthermore, she says that only two verbs that come of this form in the glorious Quran. These verbs are /PibyaDDa/ and /Piswaddal 'be black'.

Al-Swalqah (2008: 98) asserts the previous statement and mentioned the verse that has the two verbs in Surat Al-Çimrân, i.e., verse no. 106

Idris Book III (1989: 1249-1253) adds to the meaning of being colored with a certain color another meaning, i.e. the meaning of being defected. 
Idris gives the same example of Surat Al-Çimrân and added that the meaning of being colored has other two meanings within it as follows:

1 - Becoming in a certain state

2- Reflexivity

Thus the meaning of coloring includes three meanings. Idris gave another example of coloring of, verse no. 84 of Surat Yusuf:

She explained the verb in this verse that the black color of the eye turned into white as a result of crying for long times.

- Another meaning was added by Idris to this form [?ifçalla], i.e. the indications of meanings. An example of the use of this meaning is the verb / PinqaDDal 'swoop down' of Surat AlKahf, verse no. 77 Idris explained the form of the verb /PinqaDDa/ as it is formed of the origin /naqaDa/ 'destroy'.

- Another meaning that gathers the meaning of /tafaaçala/ and the indications of meanings as the frequent reading of the verb /tazzawarl 'inclining away' of Surat Al-Kahf, verse no. 17.

\section{Form X [?istafçala]}

This form is composed by the addition of the prefix /Pista/ before the first letter of the verb /faa?/.

\section{Semantic Function of the Form [?istafçala]}

Al-Kufi (1989: 29) says that this form is the most popular form of the triliteral verbs that are derived by the addition of three letters.

Al-Kufi (1989: 63) gives a list of the meanings that are expressed by this form as follows:

1- The meaning of request. Al-Kufi gives an example of this meaning, i.e. the verb /Pistaxrajal 'extract', verse no. 76 of Surat Yusuf.

2- The meaning of adoption

3- The meaning of becoming in a certain state

4- The meaning of briefing a certain saying 
5- The meaning of discovering a certain state or adjective of someone or something

6- The meaning of reflexivity of the form [?afçala]

7- The meaning of other forms such as [tafaççala], [?iftaçala], [?ifçalla] and [faççala].

8- The meaning of doing without [façala].

\section{Morpho-Semantic Shifts of Certain Verb Forms of the Glorious Qur'an}

\section{Definition of Morpho-Semantic Shift}

Mishry (2014: 25) quotes from Ibn Al-muçtaz his definition of Shift as follows "as for the Shift /Riltifaat/, it has been defined according to the Rhetoric Scholars as the /çuduul/ 'refrainment' from a certain style of speech to another one that is contradicting to the first" Mishry adds that in this previous quotation a hint that the Shift equals in meaning the refrainment so that the reasons justifying the shift are the same ones that justify the refrainment.

Mishry quotes from Hassaan his definition for Refrainment that "leave of the origin or contradiction of the rule, but this leave or contradiction has been promoted so that it turned to be one of the criteria through which language rules are measured" Mishry (2014: 24). Mishry (2014: 23) adds that Al-Musdy translated the foreign term (ECART) as the /Pal-Pinziah/ 'deviation' or the /Pat-tajaawuz/ 'transcendence' which means contradicting the origin.

Al-Qeliiny (2015: 2) quotes from Ibn Yahya Al-çalawi his definition of Shift as the refrainment from a certain style of speech to another one that is contradicting the first one. AlQeliiny defined Shift as deviation which means the deviation of speech from its direction and the refrainment from the style to another style. Other names have been given to this phenomenon as /Pal-PinSrâf/ 'Resolution', /Pat-talawwun/

\section{1}


'Coloration' \& /muxaalafat muqtaDa PaZ-Zaahir/ 'Contradicting the apparent context requisite'.

Hassan (2009:6) has defined Morpho-Semantic Shift as leaving the measuring form and adopting another form in order to express a certain semantic indication that is not expressed by the first form. This addition in letters according to certain measures and defined forms in Arabic language is known as /Pal-Pištiqaaq/ 'Derivation'.

\section{Some Examples of Qur'ânic Morpho-Semantic Shifts of Verb Forms}

The following are some pairs of verb forms will be presented according to the following order:

The verb, its form, the semantic indication of this form and the special semantic indications added to the form in the Glorious Qur'ân.

\subsection{7. /tabaça/ 'follow' - /Rittabaça/ 'imitate':}

The verb /tabaçal [façala] is used in Surat Al-Baqarah, verse no. 38:

"then whoever follows My guidance, then no fear will be on them, neither will they grieve."

It is shifted to the verb /Pittabaçal [?iftaçala] in Surat Ta-Ha, verse no. 123.

"then whoever closely follows My guidance, so he will not err away, nor will he be wretched;"

According to the previous parts of this chapter, the form [?iftaçala] indicates exaggeration so that it needs that the doer of the verb makes more efforts doing the verb [?iftaçal] than those are made doing the verb [façala].

According to Al-Fayumi (2010: 154), the verb /tabaça/ means that the person follows the guidance of Allah initiatively, instinctively and without feeling any burden. But the verb /Pittabaça/is used to express the power of will and the strength of determination. It also expresses gathering the powers in a 
sincere manner so that it turns to be spontaneously and instinctively.

As-Samerra'i (2008: 22) added in his explanation of the verb /Pittabaça/, in Surat Az-Zumar, verse no. 18 that the verb means the exaggeration of following which is a rank higher than the mere following.

"Who listen to the Saying (and) so closely follow the fairest of it."

Al-Kufi (1989: 158) agrees with the previous opinion that the two verbs /tabaça/ \& /Pittabaça/ have the same meaning with the addition of the merit of exaggeration to the form /Pittabaça/. She quoted from Ibn fares that the origin of /taa?, baa? \& çayn/ has the meaning of following and tracing.

Hindaawi (2008: 133) adds that the form [?iftaçala] indicates the studiousness and making efforts. He mentions an example of the verb /Pittabaça/ in Surat Al-Açraf, verse no. 3:

"Closely follow what has been sent down to you (, i.e. the believers) from your Lord, and do not ever follow patrons apart from Him; little are you mindful!",

Aĥmad (2015: 162-3) also compares between two verses use the form /tabaça/ and /Pittabaçal, i.e. Surat Al-baqarah, verse no. 38:

"We said, Get down out of it altogether, then, if ever there should definitely (The verb has an emphatic ending, thereby saying that guidance will come) come up to you guidance from Me, then whoever follows My guidance, then no fear will be on them, neither will they grieve."

\section{Surat Ta-Ha, verse no. 123:}

"Said He, "Get down, you two altogether out of it; some of you an enemy to some (others); yet, in case ever there definitely comes to you from Me guidance, then whoever closely follows My guidance, so he will not err away, nor will he be wretched;" 
Aĥmad comments on the use of the verb / Rittabaçal of Surat Ta-Ha that the previous context to the verse stated that Satan had made a lot of efforts to convince Adam to eat from the banned tree, therefore the efforts made by Satan to convince Adam and his sons to disobey Allah should be faced by a lot of efforts to obey Allah and disobey Satan so the verb / Pittabaçal is more suitable than Itabaça/ to express this meaning.

\subsection{8. /jaa?a/ -/Pajaa?a/:}

The first verb comes in the form of [façala], an example of this form as being intransitive comes in Surat Saba', verse no. 49:

"Say, The Truth has come; and in no way (can) untruth start (anything) and in no way (can) it bring back (anything)."

It is used as a transitive verb in Surat Aŝ-Safaat, verse no. 84: "And surely of his sect indeed was Ibrahîm (Abraham) As he came to his Lord with a sound heart,"

According to Al-Kufi the intransitive verb can be changed into transitive by addition of /hamzah/ at the front of the verb, thus the verb /jaa?a/ 'come' is turned to be /Pajaa?al, the only example of this form is in Surat Maryam, verse no. 23: Al-Kufi (1989: 102). "Then the birthpangs made her come to the trunk of the palm-tree."

Al-Kufi adds that the verb in this form is used to express obligatory as Mary out of being tired of birthpangs, she has been obliged to come to the trunk of palm-tree.

Hindaawi (2008: 121) asserts this opinion of Al-Kufi that the form [?afçal] of the verb /jaa?a/ is used to express obligatory, as Mary was obliged to resort to the palm-tree.

Musa also confirms this opinion saying that that hardness of the situation and difficulty of obligatory are the reasons of the action that Mary did. Musa (2006: 137).

Al-Fayumi (2010: 184) differs with the previous explanation of the verb Ifarajaa?ahal as he considers the verb of the origin Ifaja?al in the form [faaçala], he explains the verse as Mary has 
been surprised by the birthpangs - in a manner that should pleasant her- so that she resorted to the palm-tree.

\subsubsection{Ixadaça / 'deceive' -/ xaadaça/ 'equivocate':}

The two verb forms have been mentioned in Surat Al-Baqarah, verse no. 9

They try to deceive Allah and (the ones) who have believed, and in no way do they deceive (anyone) except themselves, and in no way are they aware.

According to Hindaawi (2008: 125), this form [faaçala] is used to express the meanings of reciprocation, conquering and following. But the form is used in this verse to express one or all of four meanings quoted by Hindaawi from AzZamakhshari as follows:

First, the behavior of the hypocrites shows them as believers whereas they are not as if they could deceive Allah and the believers so that they imagine that they could deceive Allah, also Allah Subhaanahu orders the believers to treat them as Moslems as if they are believers but Allah, His messenger and the believers know that they are not, so that they behave as if they deceive the hypocrites.

Second, the verb is used in this form to depict their beliefs towards Allah Subhaanahu as they-in fact- do not believe in Allah nor His Majesty.

Third, Allah Subhaanahu mentions His Glorious name to express His Messenger as His Messenger is His Khalif on earth.

Forth, Allah Subhaanahu mentions His Glorious name to express the great relation of /RixtiSaaS/ 'specification' between Allah and the believers so that when the hypocrites deceive the believers, it seems as if they deceive Allah.

Hindaawi comments on the quotation saying that all the previous justifications can be accepted and he can confirm the first one more than others. 


\subsubsection{0. /saqaa/ 'supply with water' - /Pasqaa/ 'water':}

The verb /saqaa/ comes in the verb form [façala] and the verb /Pasqaal, in spite of the fact that the /hamzah/ can be added to the form [façala] of certain verbs to change it from the intransitive mood to the transitive one, the two forms of the verb /saqaa/ are transitive and they are used in the Glorious Qur'ân to express the meaning of providing water.

Hindaawi (2008: 123) mentions the semantic indications of the two verbs as follows: The verb/saqaa/ is used in Surat AlInsaan, verse no. 21:

"and their Lord will give them to drink a drink most pure."

The verb /Pasqaa/ is used in Surat Al-Mursalaat, verse no. 27:

"And We made therein lofty anchorages, (i.e., mountains) and We made you to drink water grateful (to taste)."

Hindaawi quotes from Al-Fairuzabady that the verb /saqaa/ means that to give someone something to drink but the verb /rasqaal means to guarantee a source of water to drink whenever he wants, so that the word /Pisqaa?//is more rhetoric than the word /saqy/.

Hindaawi adds that the subject of the verb /saqaa/ in the glorious Qur'ân can be Allah or any body else, whereas the subject of the verb/Rasqaa/is Allah (Subhaanahu) only.

The meaning of the verb /iasqaa/ is not only providing water but also facilitating it to be drunk. The verb /saqaa/ came in two positions in the glorious Qur'ân as its subject is Allah; in Surat Al-Insaan, verse no. 21 and Surat Ash-Shuçaraa', verse no. 79 and the verb was used in the first position to give the meaning of gratitude that people of Al-Jannah feel, and the verb in the second position gives the meaning of thanking Allah for giving water in the real world. Maybe the verb is used in this form to express the meaning of gratitude feeling. The verb is used in the rest positions of the glorious Qur'ân with creatures of Allah as subjects.

\subsubsection{1. /šaraa/ 'sell' -/ Pištaraa/ 'buy':}

The two verbs are used in, verses no. 20-21 of Surat Yusuf: 
"And they bartered him for a paltry price, (some) numbered dirhams; and they esteemed him lightly (Literally: were of the ascetics, i.e., refused to have anything to do him)"

"And he who traded him, being of Misr, (Egypt) said to his wife, Give him honorable lodging;"

Al-Fayumi (2010: 338-339) explained the use of the verb /šaraa/ [façala], instead of the verb /baaça/, i.e. to sell, saying that they sold him in spite of their desire to keep him as they estimated him and were affected by him.

The second position where the verb /šaraa/ is used in Surat AlBaqarah, verse no. 102: "and miserable indeed was (that) for which they bartered themselves, if they had known (the Truth)."

Al-Fayumi explained that the use of this verb is to express the verb sell because their souls are dear to themselves and they should keep them from harm and torture but in spite of that they did some deeds that they liked but led them to Hell. So that Allah /Subhaanahu/ uses the verb /šaraa/ instead of /baaça/ to express their meaning.

The verb /iištaraa/ [?iftaçala] means to buy and is used to express this meaning in the glorious Qur'ân.

\subsubsection{2. /Sabara/ 'be patient' - /Saabara/ 'endure patiently':}

The two verbs are used in Surat Al-Çimrân, verse no. 200:

"O you who have believed, be patient, and vie in patience, and be garrisoned (, i.e. Keep a standing army ready to defend you) and be pious to Allah, that possibly you would prosper."

The verb /Sabara/ comes in the form [façala], whereas the verb Saabaral comes in the form [faaçala].

Ash-Shaçraawi (2006: IV/1973-1974) in his exegesis differentiates between the two verbs saying that in your life you will find something that you hate so that Allah (Subhaanahu) orders you that you should be patient. But if the hateful thing happens to you as well as your enemy and you find that your enemy is facing that through patience too. Then 
what should you do? In this situation, Allah (Subhaanahu) orders you that your patience should be greater than his one so that your patience should exceed his one.

Ash-Shaçraawi adds that there should be a competition in patience and the use of the verb in this form [faaçala] comes to be similar in form to the verb /naafasa/ which was used to express the length of time that the competitors can keep themselves without breathing underwater. The verb /naafasa/ is derived from the noun /nafas/ which means breath.

\subsubsection{3./faraqa/ 'differentiate' - /farraqa/ 'separate':}

Al-Matçani (2014: 63-67) differentiates between the two forms saying that:

The noun of the first form is / Ralfaraq/ and the noun of the second form is / Rat-tafriiq/. Concerning the difference in meaning, the language differentiates between the two as the first one is used to express the separation of the moral things such as the separation between the truth and the untruth and the second form is used to express the separation between the material things as the parts of the body of the sheep.

- Al-Matçani mentioned some examples of the first form taken from the Glorious Qur'ân as follows:

Note: All the examples quoted from Al-Matçani henceforth are taken as a whole and with the same arrangement made by him -Surat Al-Baqarah, verse no. 50: "And (remember) as We separated the sea for you. So We delivered you"

- Surat Al-Maa'idah, verse no. 25: "So distinguish between us (Literally: part between us and "between") and the immoral people."

- Surat Ad-Dukhaan, verse no. 4: "Therein every Wise Command is distinctly (decreed),"

- Surat Al-Israa', verse no. 106: “And (this is) a Qur'ân; We have distinctly separated (its verses) that you may read it to man-kind staidly, (Or: at intervals)" 
Al-Matçani says that two of the above examples are used according to the linguistic rules in Surat Ad-Dukhaan, verse no. 4 and Surat Al-Israa', verse no. 106 as these are moral not material things but the other two verses used the form with material things. Using the form /faraqa/ with material thing is contradicting the linguistic rules, so why this form is used in these two positions?

Al-Matçani answers this question saying that the form /farraqa/ is used to express the separation of the material things when they are strongly connected and cohesive and this thing cannot appear in the case of sea water so the form /faraqa/ is preferred in this position.

Concerning the separation of the bodies of the Prophet Moses and the unbelievers, the form /faraqa/ is also preferred as the relation between him and his brother as group and the unbelievers as another group is a weak one.

Thus Al-Matçani states the criterion of the use of the form /faraqa/ in the Glorious Qur'ân as follows:

First, the use of the form /faraqa/ with the moral and not material things as that linguistic rules use it.

Second, the form /faraqa/ is used with the material things that have weak relations between them as the sea water.

Also, the form /faraqa/ is used with the weak relations among people such as the relation between the prophet Moses and the unbelievers.

- Examples of the use of the form /farraqa/ in the Glorious Qur'ân according to Al-Mațçani: - Surat TA-Ha, verse no. 94: "I was apprehensive that you would say, You have caused disunity among the Seeds (Or: sons) of Israel"

- Surat Al-Ançam, verse no. 159:

"Surely the ones who have caused disunity in their religion and (become) sects, you are not one of them in anything;"

- Surat Al-Baqarah, verse no. 285:

"We make no distinction between any of His Messengers."

- Surat An-Nisaa', verse no. 150: 
"and would make a distinction between Allah and His Messengers,"

- Surat Al-Baqarah, verse no 102:

"they learned that by which they could cause separation between a person and his spouse."

- Suarat Al-Çimrân, verse no. 105:

"And do not be as the ones who were disunited and differed (among themselves)",

- Surat Al-Ançam, verse no. 153:

"and do not follow the (other) ways, or then they would make you part away from His way.

- Surat Al-Çimrân, verse no. 103:

"And adhere firmly to the Rope (i.e. the Covenant of Allah= the Qur'ân) of Allah, altogether, and do not be disunited;"

- Surat An-Nisaa', verse no. 130: "And in case they (both) part (from each other), Allah will enrich each (of them) of His Embracement;"

-Surat Ar-Rum, verse no. 14: "And on the Day when the Hour comes up, upon that Day they will part (from each other)."

Al-Matçani comments on the use of the form /farraqa/ in the previous ten forms as follows:

The form is used in eight positions according to the linguistic rules to express the separation of the material things in the following subjects:

The separation of the sons of Israel

The separation of the messengers of Allah

The separation of the two spouses

The separation of the group of believers

The separation of the unbelievers and their idols

The use of the verb /farraqa/ contradicts the rule in one subject, i.e. the religion that is because the religion is made similar to the strong material things.

Al-Matçani summarizes his notes about the use of the two forms as follows: 
First, the moral relations whether they are between the moral things or the material things.

Second, the material relations that exist only in the material things.

Thus, verse no. 94 of Surat Ta-Ha used the form /farraqa/ instead of /faraqa/ to express the strong relations of the sons of Israel as if they are a strong building. Also, the form is used in the rest of examples for the same reason, i.e. expressing the strong relations even if they are moral.

Al-Maţçani adds that the rhetorical reason of the use of this form is one of the two following:

The first is a declarative metaphor to liken the moral relation among the prophets to a very strong and coherent building.

The second reason is an implied metaphor that likens the separated material bodies to the bodies that are strongly constructed organic bodies.

\subsubsection{4. / kasaba/ 'gain' -/ Piktasaba/ 'earn':}

The two verbs have been used in the following verse of Surat Al-Baqarah, verse no. 286: "Allah does not charge a self (anything) except its capacity; it has whatever it has earned, and against it is whatever it has acquired."

Hindaawi (2008: 130) explains the use of the verb /kasabal saying that the verb/Piktasaba/ is used to indicate the evilness so that the form [?iftaçala] is chosen to express the studiousness and exaggeration. Hindaawi quoted from Sibawayh that the verb /kasaba/ means to get, whereas the verb /Piktasaba/ means making efforts, studiousness and uneasiness. Sibawayh added that the choice of this form [?iftaçala] indicate that the evilness is done in contradiction to the traditions and good instinct so that the doer of evilness try the fraudulence.

Hindaawi quotes from Az-Zamakhshari that the form [?iftaçala] is used to indicate the exaggeration and that the evilness overcome the goodness in the tempers of the person identified in this verse. 
So that the exegeses can complete the meaning of the two verbs as follows:

"it has whatever it has earned (of good deeds) and against it is whatever it has acquired (of bad deeds)."

Hindaawi (2008: 131-132) adds that the verb /kasabal [façala] is used in the glorious Qur'ân with the good deeds and the bad deeds, whereas the verb /Piktasaba/ [?iftaçala] is used with the bad deeds only.

An example for the use of /kasabal with bad deeds is the following verse of Surat Al-Baqarah, verse no. 81:

"Yes indeed, whoever has earned an odious deed and his offense(s) have encompassed him,"

Hindaawi explains the use of the verb /kasaba/ with bad deeds that the doer of these things has become familiar with them so that he finds no difficulty doing them so the verb refers to the easiness that the person does his deeds as if he is doing good deeds.

Al-Kufi (1989: 59) adds that the form [Piftaçala] is used to indicate making efforts and adopting and that explains the use of the verb /Piktasaba/ to refer to gathering money as in the verse of Surat An-Nisaa', verse no. 32:

"To the men is an assignment from what they have acquired, and to the women is an assignment from what they have acquired."

\subsubsection{5. /madda/ 'spread' -/ Pamadda / 'extend':}

Al-Matçani (2014: 107-111) quotes from Ar-Ragheb that both forms have a trileral origin and that their indications in language is that the form /Pamadda/ is used to express the liked matters and the form /madda/ is used in unlike matters. The question that Al-Matçani arouses is if that is the approach of using these forms in language, what is the approach of the using the forms in the Glorious Qur'ân? To answer this question, Al-Matçani gives the following examples: 


\section{Examples of the form /madda/:}

- Surat Ar-Raçd, verse no. 3:

"And He is (The One) Who extended the earth and made therein anchorages and rivers;"

- Surat Al-Furqan, verse no. 45:

"Have you not regarded your Lord, how He has extended the shade? And if He had so decided, He would indeed have made it still."

- Surat Al-Hijr, verse no. 19:

"And the earth-We have extended it and cast on it anchorages, (i.e., mountains)"

- Surat Al-Hijr, verse no. 88 \& Surat Ta-Ha, verse no. 131:

"Do not definitely extend forth your eyes to what We have given pairs of them to enjoy;"

- Surat Maryam, verse no. 79:

"Not at all! We will soon write down whatever he says, and We will grant him an extension (Literally: extend him an extension) of torment."

- Surat Maryam, verse no. 75:

"Say, Whoever has been in errancy, then indeed The AllMerciful will grant him an extension of days (Literally: extend for him an extension of days)"

- Surat Al-Ĥjaj, verse no. 15:

"Whoever has (ever) surmised that Allah will never give him victory in the present (life) and the Hereafter, then let him extend forth a means to the heaven, thereafter let him cut it off. Then let him look (for himself): does his plotting definitely put away what enrages him?"

- Surat Luqman, verse no. 27:

"And if whatever tree ( $s$ ) in the earth were pens, and the sea (and) seven more seas even after it (were) to replenish it, (yet) in no way would the Words of Allah be depleted."

- Surat Al-Baqarah, verse no. 15:

"Allah mocks them and grants them extension in blundering in their inordinance." 
- Surat Al-Açrâf, verse no. 202:

"And their brethren reinforce them into misguidance, thereafter they do not stop short."

- Surat Al-Inshiqâq, verse no. 3:

"And when the earth will be widely extended,"

Al-Matçani comments on the previous examples saying that:

The form $/ m a d d a /$ is used in the past and present tenses. It is used in two different contexts; one of them speaks about Man and the other one speaks about things rather than Man. If the context speaks about the Man, the form indicates evil or disliked matters and that is what happens in seven of the previous twelve verses. One of the evil things is the illegal things such as extending the eyes to what Allah Subhaanahu has given to some of his servants as the best manner of Muslim is to accept what Allah has decreed for him. The other topics of evilness are the following: the extension of torture, misguidance, inordinance and of the beliefs that contradict faithfulness. Al-Matçani continues in his comments saying that if the context speaks about other topics rather than man, the form is used to express some liked matters or good things from which we - as readers - can get a benefit lesson. The desirable topics of the rest five verses are the following:

- The extension of Earth for the benefit of people

- The extension of shade and moving it and the succession of the light after shade in a very splendid system.

- The extension of the sea to other seven seas to attract the attention to the

wideness of the knowledge of Allah.

- The extension of the Earth in the Doomsday so that the good people will get the rewards of Allah and the evil ones will get the punishment of Allah. Hence, the approach of the Glorious Qur'ân of the use of the form /madda/ is the following:

- It is dedicated to the unlike or evil things if the context of speech is about the states of Man. 
- It is dedicated to the desirable and good things if the context is about other things rather than Man.

Also, what has been mentioned by Ar-Ragheb of the use of the verb /madda/ for the expression of good and evil things but mostly to express evil, is right according to Al-Mațçani. But the differentiation between the context of speech about Man and the context about other topics is taken from the language of the Qur'ân itself and is considered one of the features of the miraculous language of the Glorious Qur'ân.

\section{Examples of /Pamadda/:}

- Surat Ash-Shuçarâ', verse no. 132,133:

"And be pious to Him Who has supplied you with whatever you know. He has supplied you with cattle (Ancam includes cattle, camels, sheep, and goats) and sons,"

- Surat Al-Isrâ', verse no. 6:

"Thereafter We turned back to you to recur (prevailing against them), and We supplied you with riches and sons"

- Surat At-Tur, verse no. 22:

"And We will supply them with fruits and flesh such as they crave for."

- Surat An-Naml, verse no. 36:

"So, as soon as he (the envoy) came to Sulayman, (Solomon) he said,

"Would you supply me with wealth?"

- Surat Al-Isrâ', verse no. 20:

"Each do We supply, these and these (too) from your Lords' gift,"

- Surat Al-Mu'minun, verse no. 55 \& 56:

"Do they reckon that whatever wealth and sons We supply them with.

We (provide them) swiftly with charitable (benefits)? No indeed, (but) they are not aware." 
- Surat Al-Çimrân, verse no. 125:

"Yes indeed, in case you are patient and pious, and (the enemy) comes up (against) you instantly, (Literally: this instant of theirs) your Lord will supply you with five thousand of the Angels, markedly swooping."

- Surat Nuĥ, verse no. 12:

"And He will supply you with riches and sons,"

- Surat Al- Çimrân, verse no. 124:

"Is it never sufficient for you that your Lord should supply you with three thousand of the Angels sent down (upon you)?"

- Surat Al-'Anfal, verse no. 9:

"so He responded to you that, I am supplying you with a thousand Angels in successive ranks."

Al-Matçani comments on the previous examples saying that the verb /?ammada/ - /yamiddu/ has been repeated ten times and the context of the use of the verb in all the ten times indicates liked and desirable things. These desirable things included the well promised matters and the honest statements.

The last question that Al- Matçani arouses is: why there is a difference between the topics that are expressed by the form /madda/\& /Pamadda/ when the context speaks about Man? The answer that Al- Matçani found is that the source of /maddal, i.e. /Ralmadda/ means / Raljarra/ or / Ralsaĥb/ dragging, whereas the form /Pamdda/ has the source /Pimdaad/ supply which means the increase in the good and reinforcement such as the reinforcement of the army.

Thus the Qur'ân differentiates between the two forms as it uses the form /madda/ to express the unlike things by Man and the form /Pamaddal for the liked and desirable things by Man. Therefore the /madda/ expresses the indignity and the /Pimdaad/ expresses the respect and dignity. Concerning what Al-Ragheb mentions about the form /Pamadda/ as it is used mostly in the liked matters and rarely in the disliked matters, this does not happen in the Glorious Qur'ân. The Qur'ânic approach in the use of the from /Pamaddal: First, its indication 
is for the liked and good only. Second, it is used for the speech about Man. Third, nothing of the form was used to express the unlike or evil things.

\subsubsection{6. /mahhala/ 'grant a delay' -/Pamhala/ 'respite':}

The two forms have been mentioned in Surat At-Tarek, verse no. 17 :

"So give the disbelievers (more) leisure; give them leisure awhile."

Hindaawi (2008: 180-181) quotes from As-Samin Al-Ĥalabi his explanation for the use of two forms in the same verse as follows:

Allah Subhaanahu when He repeated the mention of the meaning for the sake of certainty, He used two different forms. Hindaawi comments on his quotation saying that shifting from one form to anther has a certain reason more that differentiating the forms to avoid redundancy, it has another technical and rhetoric reason. The reason is that the first form /mahhala/ expresses the plenty of something, whereas the form /Ramhala/ expresses the transitivity in most cases. So the form /mahhala/ has been used at first to express plenty but when the disbelievers feel that it will be after a very long time so the form /Pamhala/ appeared in the same verse to avoid weakness and disparity that may come in the hearts of the persons who call for Islam. That is to indicate that even if the torture will happen after a very long time, it surly will come true. AzZamakhshary added that the first form /mahhala/ has its own role in supporting the Prophet (PBUH) with pacification and patience. That means that Allah Subhaanahu asks his prophet neither to advocate Allah asking for their torture nor to ask Allah for hurrying their torture.

\subsubsection{7. /nabba?a/ 'inform' -/ Panba?a/ 'announce':}

The two forms of the verb are transitive whereas the triliteral form of the verb is intransitive and can only be used while 
being followed by a preposition /çala/ or /min/ as Al-Kufi (1989: 264) mentioned, she gave examples of the triliteral form as follows:

a. /naba?a çala Palqawm/, i.e. discovered them.

b. /naba?a min ParD-in Pila ParD/, i.e. to get out of it.

The two forms of the verb have been mentioned of Surat AtTaĥîm, verse no. 3:

"And as the Prophet (entrusted) a secret discourse to some of his spouses, then as soon as one of (them) (fully) informed (another) of it, and Allah disclosed it to him, he acquainted (her) of some part of it, and passed over (Literally: veered away from) (some) part. Then, as soon as he (fully) informed her of it, she said, "Who has informed you of this?" He said, "The Ever-Knowing, The Ever-Cognizant has (fully) informed me."

Al-Qeliiny (2014: 114-117) explained the shift between the two forms in the previous verse as follows:

First he said that /nabba?a/ is used to indicate the exaggeration and confirmation as stated by Al-Aŝfahaani in explaining this verse. The first form /nabba?al is used to express the certain knowledge of the prophet (PBUH) of what has happened by one of his wives. Whereas, when she asked Him she expressed her limited knowledge that she thought that one of his other wives or someone else told Him. That was the reason of the first shift /nabba?ahal - /Panba?aka/.

The second shift /Panba?aka/ -/nabba?ani/ has been used to express that The Ever-Knowing, The Ever-Cognizant who has informed His prophet. The object of the verb that she used /haaða/ was not used for a second time to indicate the greatness of the knowledge that the prophet has been informed in comparing to what she referred to using the pronoun /haaðal.

Al-Qeliiny quotes from As-Samerra'i that the reason of shifting is not the exaggeration but the plenty of speech that has been said as the wife of the prophet (PBUH) has used the verb 
/Ranba?aka/ to refer to a part of knowledge so she used the pronoun /haaðal 'this' as an object. But, the prophet (PBUH) used the verb /nabba?ani/ to refer to the plenty of knowledge that Allah the Al-Mighty has informed him.

Al-Qeliiny adds that An-Naçemi refers to the plenty of speech as well as the length of time needed to inform this speech. AnNaçemi explains the length of time saying that referring to the first verb done by the prophet's wife, she had hesitated before informing others and the hesitation takes time and the information takes time so the verb /nabba?a/ is used to express that the action takes more time than the mere information. AnNaçemi continues that the prophet (PBUH) has informed his wife some of the speech, and the action of informing is done during a long period of time so the verb /nabba?aha/ has been used. But when the prophet's wife referred to the secret as a whole as she knew it, she used the verb /Panba?aka/ to indicate the short time. The prophet (PBUH) answered her that Allah the Al-Mighty informed him and that takes time to explain what had happened.

Al- Qeliiny states that the verb /Panba?a/ is used in only four positions of the Glorious Qur'ân and all of them refer to short time. Whereas, the verb /nabba?a/ is used in forty-six positions such as the verb in, verse no. 78 of Surat Al-Kahf as the narration of three stories needed time. Also, the verb is used in verse no. 36 of Surat Yusuf as they asked him to explain what they had seen in their dreams.

Surat Al-Kahf: "I will soon (fully) inform you regarding the interpretation of what you were unable to (endure) patiently." Surat Yusuf: "Fully inform us of its interpretation; surely we see you (are) (one) of the fair-doers."

As-Samerra'i states that the verb /nabba?a/ is used to express confirmation as in many examples such Surat Al-Hajj, verse no. 72, Surat Al-Maa'idah verse no. 60, Ash-shuçarâ', verse no. 222 , etc. In the previous-mentioned examples the use of the 
form [faççala] is used in addition to the interrogative mood to express confirmation of the mentioned meanings.

\subsubsection{8. /Panjaa/ 'protect' - /najjaa/ 'deliver':}

Al-Fayumi $(2010: 151,152)$ mentions two verses used the two forms narrating the story of the Prophet Lut (çalayh ?assalaam) as follows:

Surat An-Naml, verse no. 57:

"So We delivered him and his family, except his wife; We determined she should be of the laggards."

Surat Ash-Shuçrâ', verses no. 170,171:

"So We delivered him safely and his family all together, Except an old woman among the laggards."

Al-Fayumi comments on the use of the two forms saying that the first form /Panjaal means that the action of saving happened gently and quickly whereas the second form /najjaal expresses the firm will and strong fortification.

Another example that has the two forms of verbs is in verse no. 103 of Surat Yunus:

"Thereafter We will safely deliver Our Messengers and the ones who have believed. Thus, as is truly (binding) on Us, We will deliver the believers."

The form /najjaa/ is used to express the saving of the groups of believers during the successive years and successive generations. The form /Panjaa/ is used to express the swiftness and immediacy.

Al-Qeliiny (2014: 121-132) mentions two other examples of the two forms taken from Surat Al-Baqarah, verses no. $49 \&$ 50 :

"And (remember) as We safely delivered you from the House of /Firaawn/ (Pharaoh) (who were) marking you out for odious torment, constantly slaying your sons, and sparing alive your women; and in that (Literally: these "atrocious acts") was a tremendous trial from your Lord." 
"And (remember) as We separated the sea for you. So We delivered you and drowned the house of /FirGawn/ (pharaoh) (while) you were looking (at them)."

Al-Qeliiny comments on the two verses saying that both forms have the meaning of saving Man of the threats that face him but each one of them has its own additional meanings. The additional meanings of the form /najjaa/ are the exaggeration and confirmation. There are indications to the threats from which the saving happened. The form /najjaa/ has an indication that the saving has been repeated for many times and that the threats were many. The threats were the torture for the sons of Israel and killing their offspring, keeping their wives alive. Whereas the form /Panjaa/ indicates that the saving happened for once only and that there was only one threat, i.e. the drowning in the sea.

Other examples of the two forms in a successive arrangement mentioned by Al-Qeliiny are in Surat Al-'Ançam, verses no. 63, 64:

"Say, Who safely delivers you from the darkness(es) of the land and the sea? You invoke Him supplicating and (covertly) concealed, "Indeed in case He delivers us from these, indeed we will definitely be among the thankful."

"Say, Allah safely delivers you from them and from every agony; thereafter you associate (others) with Him."

Al-Qeliiny comments on the previous two examples saying that there was a shifting from the form /najjaa/ that indicates the exaggeration and intensification to the form /Panjaa/ then another shifting in the second verse to the first form /najjaa/. The form /najjaa/ means that the saving has been repeated for many times whereas the second form indicates that people have put a condition that Allah saves them for one time only, so that they will be thankful.

Also, Al-Qeliiny mentions two examples of the form /Panjaa/ in Surat Yunus, verses no. 22 \& 23: "He is The (One) Who makes you to travel on the land and the sea till, when you are 
in the ships, and the ships run with them with a good wind, and they exult with it, there comes to them (i.e. the ships) a tempestuous wind, and waves come on them from every place, and they expect that they are encompassed. They invoke Allah, making the religion His faithfully, "Indeed if You deliver us from these (,i.e. the wind and the waves) indeed we will definitely be of the thankful."

"Yet as soon as He has delivered them, only then do they (transgress) inequitably in the earth untruthfully. (Literally: with other than the truth) $O$ you mankind, surely your inequity is only against yourselves. The enjoyment is of the present life; (Literally: the lowly life, i.e. the life of this world) thereafter to Us will be your return, then We will fully inform you of whatever you were doing."

Al-Qeliiny comments on these two verses saying that in the similar verses of Surat Al-'Ançam the saving was from the darkness of land and sea and from every distress so the repetition of the action of saving needs the form /najjaa/ but in Surat Yunus, the saving happened for one time only.

Al-Qeliiny made a comparison between the narrations of the story of the prophet Nuh in Surat Al-'Açrâf, verse no. 64 and Surat Yunus, verse no. 73:

"So they cried him lies; then We delivered him, and the ones with him, in the ship (s), and We drowned (the ones) who cried lies to Our signs; surely they were a willfully blind people."

"Yet they cried him lies; so We safely delivered him and the ones with him in the ship (s), (The word /fulk/ (ship) can mean singular or plural) and We made them succeeding each other, and We drowned the ones who cried lies to Our signs; so look into how was the end of them that were constantly warned."

Accordong to Al-Qeliiny, both forms are used to indicate transitivity but the form /najjaa/ indicates the exaggeration and comprehensiveness. The form in this verse indicates that the saving was not for the prophets and the believers only but all the animals and creatures on the ship. 
Another comparison is made by Al-Qeliiny of the narrations of the story of the prophet Lut as follows:

Surat Al-Açrâf, verse no. 83: "So We delivered him and his family, except his wife; she was one of the laggards."

Surat An-Naml, verse no. 57: "So We delivered him and his family, except his wife; We determined she should be of the laggards."

Surat Aŝ-Safât, verses no. 133-135: "And surely /Lût/ (Lot) is indeed one of the Emissaries," "As We safely delivered him and his family all together,"

"Except an old woman among the laggards;"

Al-Qeliiny comments on the three narrations saying that the form /Panjaa/ indicates that Allah saved His prophet and the believers and the form /najjaa/ indicates the confirmation and comprehensiveness of the salvation.

As-Samerra'i (2006: 66-72) has a different view concerning the use of the two forms. Comparing the two verses of Surat AlBaqarah, verses no. 49,

50. This view is that the use of the form /Panjaa/ indicates that the believers have lasted in the sea for a short time whereas they have passed long time in the torture of pharaoh during his reign so the form /najjaa/ is more suitable to indicate the long period of time.

Another verse that used the form /Panjaa/ and mentioned by As-Samerra'i is, verse no. 24 of Surat Al-Çankabut when narrating the story of saving the prophet Ibrahim from Fire.

"Yet in no way was the answer of his people (anything) except that they said, Kill him or burn him away!" Then Allah delivered him from the fire. Surely in that are indeed signs for a people who believe."

As-Samerra'i states the same explanation of the use of this form saying that the prophet Ibrahim didn't last in Fire for a long time.

Another comparison is made by As-Samerra'i for three verses have the two forms as follows: Surat Al-Isrâ', verse no. 66, 
67: "Your Lord is (the One) Who urges on for you the ships in the sea that you may seek of His Grace; surely He has been Ever-Merciful towards you."

\subsubsection{9. /Panzala/ 'bring down' - /nazzala/ 'send down':}

Al-Fayumi (2010: p.153) mentioned two examples of the form /Panzala/ as follows:

1- Surat Ash-Shura, verse no. 17: "Allah is (He) Who has sent down the Book with the Truth, and (also) the Balance;"

2- Surat Al-Çimrân, verse no. 7: "He is The (One) Who has sent down upon you the Book, "'

And other two examples of the form /nazzala/ as follows:

1-Surat Al-Furqân, verse no. 1: "Supremely Blessed is He Who has sent down the all-distinctive Criterion upon His bondman that he may be a warner to the worlds."

2- Surat Al- Çimrân, verses no. 2, 3: "Allah, there is no god except He, The Ever-Living, The Superb Upright Sustainer."

"He has been sending down upon you the Book with the Truth, sincerely (verifying) what was before it (Literally: between its two hands), and He sent down the /tawrah/ (The Book revealed to /muusal 'Moses') and the /Pinjil/. (The Book revealed to /Pisa/).'

He added that the verses of Surat Al- Çimrân, verse no. 2-4 have the two forms /Panzalal - Inazzala/: "Allah, there is no god except He, The Ever-Living, The Superb Upright Sustainer."

"He has been sending down upon you the Book with the Truth, sincerely (verifying) what was before it (Literally: between its two hands), and He sent down the /tawraah/ (The Book revealed to /muusa/ 'Moses') and the /Pinjil/. (The Book revealed to /Siisa/)."

"Earlier, as guidance to mankind, and He sent down the all-distinctive Criterion."

He comments on the use of the first form /Panzala/ that the form means holding the matter with a firm control and sending 
it from a high position, whereas the form /nazzala/ means holding all the sides and minutes of the matter strongly and wisely. He added that the form /nazzala/means saving the sent matters with a strong and surrounding protection.

As-Samerra'i (2009: 66-68) differentiates between two groups of verses, i.e. verses no. 51-54 of Surat Ta-ha \&, verses no. 912 of Surat Az-Zukhruf

Surat Ta-Ha: "He said, Then what about the earliest generations?"

"He said, The knowledge of them is in the Providence of my Lord, in a Book; my Lord does not err, nor does He forget."

"He who has made the earth (as) a cradle for you, and inserted ways therein for you, and sent down water from the heaven; so We have brought out therewith pairs of divers (kinds of) growth."

"Eat (thereof), and pasture your cattle! Surely in that are indeed signs for ones endowed with intelligence."

Surat Az-Zukhruf

"And indeed in case you ask them, Who created the heavens and the earth? Indeed they will definitely say, The EverMighty, The Ever-Knowing created them."

"(He) Who made the earth to be a cradle for you and made ways for you therein that possibly you would be guided."

"And Who has been sending down from the heaven water with determined estimate; so We have made to rise again thereby a deceased country; thus you will be brought out."

"And Who created the pairs, all of them, and made for you of the ships and the cattle (?ançaam includes cattle, camels, sheep and goats) (some) that you ride."

Concerning the two forms of the verb, As-Samerra'i stated that the form used in Surat Ta-Ha is /Panzala/ whereas the form used in Surat Az-Zukhruf is /nazzala/. In his comment on the use of the different forms, As-Samerra'i mentioned the context of the two forms saying that the form Inazzala/ indicates the intensity\& exaggeration and the role of the sent water in Surat 
Az-Zukhruf is repeated and more important that its counterpart in Surat Ta-ha. The water in Surat Ta-Ha is needed to help in growing the plants whereas in Surat Az-Zukhruf it is needed in reviving a deed village with all the creatures living on its surface including the Man, plants, insects \& animals. AsSamerra'i added that the form /ranzala/ has been mentioned three times in Surat Ta-Ha whereas the form /nazzala/ has been mentioned once in both Surahs. Therefore, the form /Panzala/ is repeatedly mentioned but the form /nazzalal has the repetition as one of its indication so each form is more suitable in its position.

Tabl differentiates between the two forms by a more detailed comparison saying that the two forms have been used in, verse no. 3 of Surat Al-çimran. Tabl (1998: 57-62).

"He has been sending down upon you the Book with the Truth, sincerely (verifying) what was before it (Literally: between its two hands), and He sent down the /tawrah/ (The Book revealed to /muusal 'Moses') and the /Pinjil/. (The Book revealed to /Pisa/)."

\subsubsection{0. /waSSaa/ 'enjoin on you' - /PawSaa/ 'advise':}

Al-Kufi (1989: 264-266) mentions certain examples of the two forms as follows:

Surat Maryam, verse no. 31: "and He has enjoined upon me prayer and

Zakat (The poor dues) as long as I am alive."

Surat Al-Çankabut, verse no. 8: "And We have enjoined upon man the

fair (companionship) to his parents"

Surat Al-Baqarah, verse no. 132: "And Ibrahîm (Abraham) enjoined his seeds (Or. sons) with this, and (also) Yaaqûb, (Jacob)"

Al-Kufi comments on these examples saying that the form /waSSaa/ is used for the religious matters such as the worship 
of Allah and prohibiting worshiping anything other, prohibiting the Indecencies, prohibiting taking the orphan's money and prohibiting killing people. The same form is used in ordering to do the good deeds such as honoring parents, fulfilling the covenants of Allah and doing the right and straight balancing. Al-Kufi added that all these matters are very important for the believers so that this form is used to indicate intensity and exaggeration.

On the contrary, the form / $2 a w S a a /$ is used for the material things related to the laws of inheritance. There is one verse only that uses the form with religious matters that are related to the acts of worship, i.e. prayer and Zakaat and these matters are punctual in daily life.

The researcher thinks that the form /?awSaa/ is used with the material and behavioral things that can be seen and observed whereas the form /waSSaal is used with the religious things that cannot be easily observed through certain acts of behavior. Therefore, they need some sort of certainty which is a feature of the form /waSSaal.

\section{Conclusion: Findings of the Study}

This study investigates the semantics of triliteral verb forms from II to X. Comparing the semantics of these forms in Modern Standard Arabic to those of the Glorious Qur'ân, the study discovers more semantics expressed by the verb forms in the Qur'ân. For example, the use of the form [faççala] and the form [?afçala] of the root /waSiya/ have different semantics in the Holy Qur'ân. The verb /waSSaa/ is dedicated to the religious matters such as the worship of Allah, prohibiting taking the orphan's money. It is also used in ordering to do good deeds such as honoring parents and fulfilling the covenants of Allah. On the contrary, the form / RawSaa/ is used for the material things related to the laws of inheritance. There is only one verse that uses the form with religious matters that 
are related to the acts of worship, i.e. prayer and Zakat and these matters are punctual in daily life.

\section{Appendix 1}

Transliteration System of the Arabic Graphemes

\begin{tabular}{|c|c|c|}
\hline $\begin{array}{l}\text { Arabic } \\
\text { Graphemes }\end{array}$ & $\begin{array}{l}\text { Articulatory Features of } \\
\text { Arabic Phonemes }\end{array}$ & $\begin{array}{l}\text { Phonemes used } \\
\text { in the Study }\end{array}$ \\
\hline 4 & Voiceless glottal stop & [?] \\
\hline ب & Voiced bilabial stop & [b] \\
\hline ت & Voiceless alveo-dental stop & {$[\mathrm{t}]$} \\
\hline$\dot{H}$ & Voiceless dental fricative & {$[\theta]$} \\
\hline ج & $\begin{array}{l}\text { Voiced alveo-palatal } \\
\text { affricate }\end{array}$ & [j] \\
\hline ح & $\begin{array}{l}\text { Voiceless pharyngeal } \\
\text { fricative }\end{array}$ & {$[\hat{\mathrm{h}}]$} \\
\hline$\dot{\tau}$ & Voiceless uvular fricative & {$[\mathrm{x}]$} \\
\hline د & Voiced alveo-dental stop & [d] \\
\hline j & Voiced dental fricative & [ð] \\
\hline J & Voiced alveolar trill & {$[\mathrm{r}]$} \\
\hline j & Voiced alveolar fricative & {$[\mathrm{z}]$} \\
\hline س & Voiceless alveolar fricative & {$[\mathrm{s}]$} \\
\hline ش & $\begin{array}{l}\text { Voiceless alveo-palatal } \\
\text { fricative }\end{array}$ & {$[\check{S}]$} \\
\hline 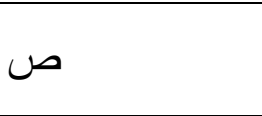 & $\begin{array}{ll}\text { Voiceless } & \text { alveolar } \\
\text { velarized fricative } & \end{array}$ & {$[\mathrm{S}]$} \\
\hline 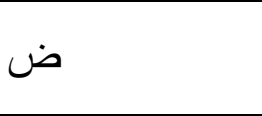 & $\begin{array}{l}\text { Voiced alveo-velarized } \\
\text { stop }\end{array}$ & [D] \\
\hline b & $\begin{array}{l}\text { Voiced alveo-dental } \\
\text { velarized stop }\end{array}$ & {$[\mathrm{T}]$} \\
\hline ظ & $\begin{array}{l}\text { Voiced dental velarized } \\
\text { fricative }\end{array}$ & {$[\mathrm{Z}]$} \\
\hline$\varepsilon$ & Voiced pharyngeal fricative & {$[c ̧]$} \\
\hline$\dot{\varepsilon}$ & Voiced uvular fricative & {$[\mathrm{g}]$} \\
\hline ف & $\begin{array}{l}\text { Voiceless labio-dental } \\
\text { fricative }\end{array}$ & [f] \\
\hline
\end{tabular}


Bulletin of The Faculty of Arts, Vol. (57), No. (2) October 2020

\begin{tabular}{|c|c|c|}
\hline ق & Voiceless alveolar stop & [q] \\
\hline ك & Voiced velar stop & {$[\mathrm{k}]$} \\
\hline ل & Voiced alveolar lateral & [1] \\
\hline r & Voiced bilabial lateral & {$[\mathrm{m}]$} \\
\hline$\dot{ن}$ & Voiced alveolar nasal & {$[\mathrm{n}]$} \\
\hline$ه$ & Voiceless glottal fricative & {$[\mathrm{h}]$} \\
\hline 9 & voiced bilabial round glide & {$[\mathrm{w}]$} \\
\hline
\end{tabular}

\section{Arabic Vowels}

\begin{tabular}{|c|c|}
\hline '_ & $\mathrm{a}$ \\
\hline ', & $\mathrm{u}$ \\
\hline $\overrightarrow{\mathrm{g}}$ & $\mathrm{i}$ \\
\hline 1 & aa \\
\hline g & $\mathrm{uu}$ \\
\hline ي & ii \\
\hline
\end{tabular}

\section{Appendix 2 - [faççala]}

\begin{tabular}{|l|l|}
\hline /baSSara/ & Make someone aware of something \\
\hline /ballaga/ & Inform \\
\hline /jannaba/ & Keep away from \\
\hline /ĥaððara/ & Warn \\
\hline /hallaa/ & Arrive \\
\hline /ĥmmala/ & Load \\
\hline /xawwala/ & Empower \\
\hline /ðakkara/ & Bethink \\
\hline /Tawwaqa/ & Restrain \\
\hline /fahhama/ & help someone to understand \\
\hline /kaffala/ & supply with sustenance \\
\hline /laqqaa/ & Encounter \\
\hline /manna/ & Favor \\
\hline /waffaa/ & Fulfill \\
\hline
\end{tabular}

Appendix 3 - [faççala]

\begin{tabular}{|l|l|}
\hline /zayyana/ & Adorn \\
\hline /saxxara/ & Employ \\
\hline /Sallaa/ & Pray \\
\hline /çazzara/ & Chasten \\
\hline
\end{tabular}




\begin{tabular}{|l|l|}
\hline /gaššaa/ & Falsify \\
\hline /qaddara/ & Estimate \\
\hline /mahhada/ & Facilitate \\
\hline
\end{tabular}

\section{Appendix 4 - [Pinfaçala]}

\begin{tabular}{|l|l|}
\hline /Pinbajasat/ & gushed out \\
\hline /PinbaçaAa/ & (was) sent forth \\
\hline /nabtagi/ & we seek \\
\hline /Pinsalaxa/ & he slipped off \\
\hline /Pinba日aqa/ & be given off \\
\hline /PinSarafa/ & Turn away \\
\hline /PinTalaqa/ & Went forth \\
\hline /Pinfajarat/ & gushed forth \\
\hline /PinfaDDu/ & Rushed \\
\hline /PinfaTarat/ & (is) cleft asunder \\
\hline /Pinfalaqa/ & it parted \\
\hline /yanqaDDa/ & about to fall \\
\hline /Pinqalaba/ & Turned \\
\hline /Pinkadarat/ & Stars become hazy \\
\hline /Pinhaara/ & Collapsed \\
\hline
\end{tabular}

\section{Appendix 5 - [?iftaçala]}

\begin{tabular}{|l|l|}
\hline /Pijtamaça/ & Gather \\
\hline /Piĥtaraqa/ & Burn \\
\hline /PixtalaTa/ & Mingle \\
\hline /Pizdaada/ & Increase \\
\hline /Pistatara/ & take cover \\
\hline /Pistawaa/ & he ascended \\
\hline /Pištadda/ & be firmly established \\
\hline /Pištaçala/ & Flare \\
\hline /PiDTara/ & forced by necessity \\
\hline /Piftadaa/ & Offer as ransom \\
\hline /Piltafata/ & Look back \\
\hline /Piltaffa/ & Furl \\
\hline /PimtalaP?a/ & Overfill \\
\hline /Pimtaaza/ & stand apart \\
\hline /Pintabada/ & Withdraw \\
\hline /PintaZara/ & Wait \\
\hline /Pintašara/ & Disperse \\
\hline /PintaSara/ & defend himself \\
\hline
\end{tabular}


Bulletin of The Faculty of Arts, Vol. (57), No. (2) October 2020

\begin{tabular}{|l|l|}
\hline /Pintahaa/ & \multicolumn{1}{|c|}{ Desist } \\
\hline /Pihtadaa/ & remain guided \\
\hline /Pihtazza/ & Stir \\
\hline /Pittasaqa/ & become full \\
\hline
\end{tabular}

\section{Appendix 6 - [Piftaçala]}

\begin{tabular}{|l|l|}
\hline /PiPtamara/ & plot against \\
\hline /Pibtahala/ & Pray humbly \\
\hline /RixtaSama/ & Dispute \\
\hline /Pixtalafa/ & Differ \\
\hline /Pirtaçaa/ & Pasture \\
\hline /Pistabaqa/ & Hasten \\
\hline /Piqtatala/ & Fight \\
\hline /Piltaqaa/ & Meet \\
\hline /Pimtaraa/ & Doubt \\
\hline
\end{tabular}

\section{References}

Abd-Alhamid, Al-Sayed Muhammad Abd-Alhamid. (2004). ItaSrif Pal-

Pafçal/ [Verb Morphology]. Cairo: Almaktabah Al-Azhariah Leltorath

Lilnashr wa Al-tawzeeç.

Ahmed, Helal Muhammad Abd-Alfadeel (2015) /tawazi Palmabaani wa

Pal-maçaani fi mutašaabih Pal-qur?an Pal-Kariim/. [The Parallelism of

Structures and Meanings in the Similar Verses of the Holy Qur'an]. Cairo:

Maktabet Al-Adaab.

Al-Fayumi, Ahmad Abd-Altawab. (2010). /çilm Pal-dalalah Pal-lugawiyah:

Diraraasah taTbiiqiyah çala Pal-qurPan Pal-kariim/ [The Science of the

Linguistic Indication: An Applied Study of the Holy Qur'an]. Cairo: 
Almaktabah Al-Azhariah Leltorath.

Alkufi, Najat Abdel-ÇaZim (1989) /Pabniyat Pal-Pafçaal/ [Structures of Verb]. Cairo: Dar Althaqafah lilnashr wa Altawziiç.

Al-Matçani, Abd-Alçathim Ibrahim Muhammad. (2014). Idirasaat jadiidah fi Piçjaaz Pal-qur?an: manahij taTbiqiah fi tawZif Pal-lugah/ [A New Study in The Miracle of the Qur'an: Applied Approaches of Language Functioning]. Cairo: Maktabat Wahbah.

Al-Qeliini, Sameh.( 2015) /Pal-jalal wa Pal-jamal fi uslub Paliltifat fi Pal-

qurPan Pal-karim./ [Majesty and Beauty of the Refrainment of the Holy

Qur'an] Cairo: Maktabet Wahbah.

Al-Saçdy, Hassan Ghazy and Al-Musawy, Muhammad Nury (2010) /dalaalat Pal-fiçl Pal-mazid biltaDçif fi Pal-qur?an PalKarim/ [Indications of the Derived Doubled Verb in the Holy Qur'an]. Imajallat kulliyat Pal-çulum Pal-Pinsaaniyah jaamiçat baabel/ [Journal of Human Sciences, Babel University].

Al-Samerra'i, Fadel Saleĥ (2008) /Pas Pilah bayaaniyah fi Palqur?an Pal-

karim./[Rhetoric Questions of the Holy Qur'an], First Edition. Al-Sharjah:

Maktabet Al-Sehabah.

Al-Sawaleqah, Sakinah Muhammad Abd-alkarim (2008). Imaçaani ziyadaat Pal-Pafcaal fi Pal-qur?an Pal-karim/. [Meanings of the Increased Letters in the Verbs of the Holy Qur'an], Moatah University. 
Al-Shaarawi, Muhammad Metwali, Khwater (2006). /tafsiir Paš-šaçrawi/ [The Exegesis of Al-Shaarawi]. Cairo: Dar Akhbar Alyoum.

Idris, Thuraya Ali Othman (1989). / PaS-Siyag Pal-fiçliah fi Palqur?an Pal-karim./ [Verb Forms of the Holy Qur'an]. Mecca: Om AlQura University, Faculty of the Arabic Language.

Hindawwy, Abd-alhamid Ahmad Yusuf (2008). /Pal-Piçjaz Pal-Sarfi fi Pal-

qurPan Pal-karim./ [Morphological Approach of the Holy Qur'an]. Bairut: Al-Maktabah Al-çaŝriyah.

Mishry, Abd-Alnaser (2014). /dalalaat Pal-çudul PalSarfi fi Pal-qur?an

Pal-karim./ [Indications of Morphological Refrainment in the Holy Qur'an].

Batenah: Al-Haj Lkhedr University, Faculty of Arts and Languages. 


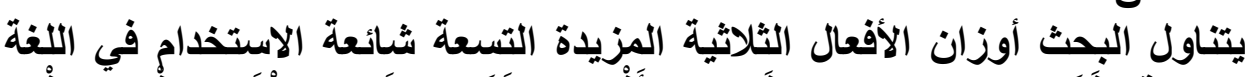

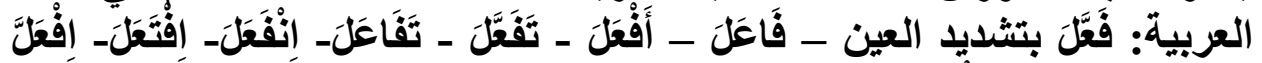

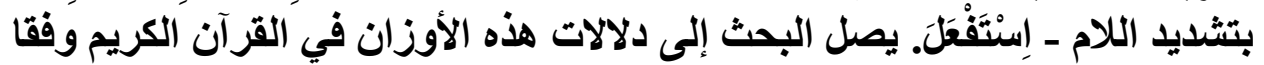

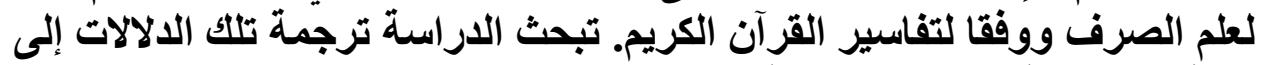

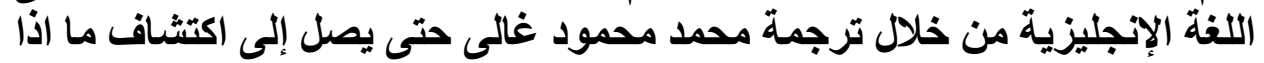

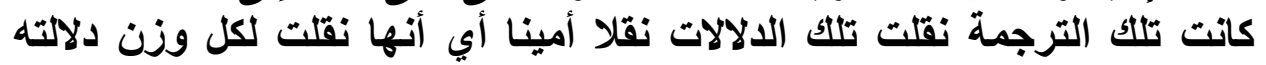

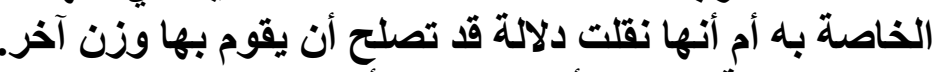

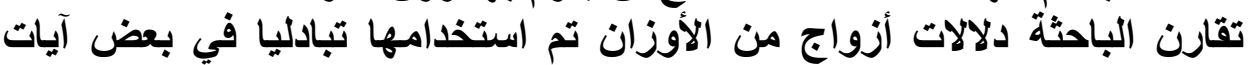

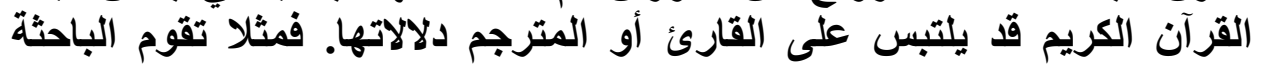

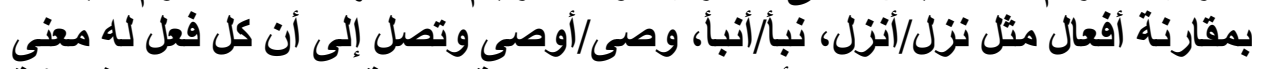

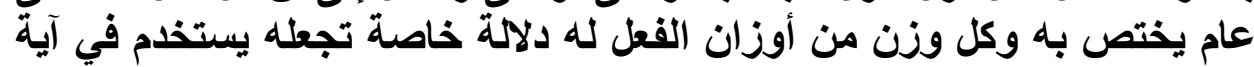

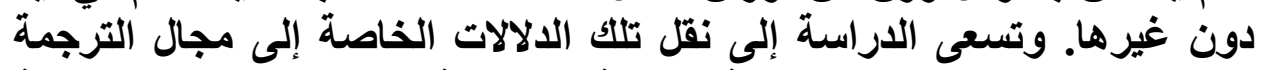

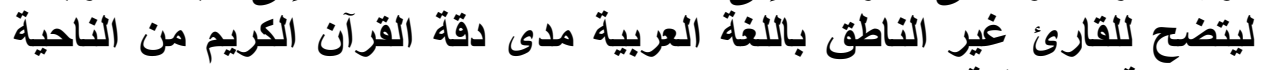
التعبيزية والبلاغية لإئ. 